\title{
Highly Selective Procedure for Trace Analysis of Platinum(IV) in Its Allied Materials
}

\author{
Mohamed A. KabiL ${ }^{\dagger}$, Shaban E. Ghazy, Ahmed A. El-Asmy and Yousery E. Sherif \\ Chemistry Department, Faculty of Science, Mansoura University, P.O. Box 15, Mansoura, Egypt
}

\begin{abstract}
4-Phenylthiosemicarbazide (HPTS) was investigated as a new collector for the flotation of platinum(IV). The metal ion forms a $(1: 2)$ pale green complex with HPTS in the aqueous solution. An intense clear green layer was formed, after flotation, by adding oleic acid (HOL) surfactant. The composition of the float is $1: 2$ (Pt: HPTS). A highly selective and sensitive spectrophotometric procedure was proposed for the determination of microamounts of Pt(IV) as its floated complex. The flotation-determination method was achieved in the $\mathrm{pH}$ range $3-7$. Beer's law was obeyed up to $6 \times$ $10^{-5} \mathrm{~mol}^{-1}(11.7 \mathrm{ppm})$. The interferences from various foreign ions were avoided by adding excess HPTS. The molar absorptivities of Pt-HPTS and Pt-HPTS-HOL systems are $2 \times 10^{3}$ and $4.7 \times 10^{3} 1 \mathrm{~mol}^{-1} \mathrm{~cm}^{-1}$ at 660 and $690 \mathrm{~nm}$, respectively. The formation constants of the species formed in the presence and absence of HOL are calculated. The method was successfully applied to the determination of $\mathrm{Pt}(\mathrm{IV})$ in its allied materials. A mechanism of flotation is suggested.
\end{abstract}

Keywords Platinum, 4-phenylthiosemicarbazide, flotation, spectrophotometry

This work represents part of an ongoing examination of applications of the flotation technique to the separation, purification and determination of platinumgroup metals. The economic importance of platinum and its uses in jewelry, catalysis, industry, manufacture of scientific instruments and medical fields ${ }^{1}$ pushed us to focus attention on evaluating a rapid and selective method for its separation and determination.

Most of the spectrophotometric methods reported for the determination of $\mathrm{Pt}(\mathrm{IV})$ are based on the formation of sparingly soluble ion-association compounds between multicharged anionic complexes (containing $\mathrm{Pt}(\mathrm{IV})$ ) and hydrophobic basic dyes:, these have some limitations, including 1) contamination of some foreign ions with the associate $^{2,3}$ may be expected, 2) serious interferences from Pd(II), Ir(IV), Rh(III), Ru(III), Hf(IV), Ce(IV) and W(VI) depressed the selectivity of the method $\left.{ }^{4}, 3\right)$ the precipitate of the chemical associate must be dissolved in a suitable solvent ${ }^{5,6}$ before the determination, 4) Beer's law is obeyed over a very narrow range ${ }^{7}$ of the analyte concentration and 5) some of these methods are timeconsuming and involve lengthy procedures.

The proposed method (solvent sublation technique) was used for the determinaiton of microamounts of $\mathrm{Pt}(\mathrm{IV})$ through the formation of a stable soluble complex with the collector, 4-phenylthiosemicarbazide (HPTS), in the oleic acid (HOL) layer. The procedure allows the direct analysis of the analyte in the organic phase directly without further treatment. Moreover, it is free from interferences with hyperselectivity. Also, it needs

† To whom correspondence should be addressed. simple apparatus and less experimental skill and is more reliable and rapid.

\section{Experimental}

\section{Reagents}

All reagents were of analytical-reagent grade. The stock solution of $\mathrm{Pt}(\mathrm{IV}), 1 \times 10^{-2} \mathrm{~mol} \mathrm{l}^{-1}$, was prepared by dissolving $1 \mathrm{~g}$ of chloroplatinic acid in $250 \mathrm{ml}$ doublydistilled water. The final concentration of $\mathrm{Pt}(\mathrm{IV})$ was standardized using an atomic absorption spectrometer. 4-Phenylthiosemicarbazide, $1 \times 10^{-2} \mathrm{~mol} \mathrm{l}^{-1}$, stock solution was prepared by dissolving the requisite amount from a sample, previously prepared ${ }^{8}$, in an aqueousethanol solution. Oleic acid stock solution $\left(6.36 \times 10^{-2}\right.$ $\mathrm{mol}^{-1}$ ) was prepared by dispersing $20 \mathrm{ml}$ of HOL (food grade, sp. gr. 0.895, provided from J. T. Baker Chemical Co.) in 11 of kerosene. The real samples of platinum alloys were obtained from the Department of Impression of Nobel Metals and Weights, Egypt.

\section{Apparatus}

The flotation cell used was a cylindrical graduated glass tube of $16 \mathrm{~mm}$ inner diameter and $290 \mathrm{~mm}$ length with a stopper at the top and a stopcock at the bottom. The spectral data were recorded on Unicam UV $2100 \mathrm{UV} / \mathrm{Vis}$ and MATTSON 5000 FTIR Spectrometers. The pH values of all solutions were measured using Hanna Instruments 8519 digital pH meter. The atomic absorption measurements were recorded using Perkin-Elmer 2380 Atomic Absorption Spectropho- 
tometer with air-acetylene flame. The optimum parameters are: wavelength, $266 \mathrm{~mm}$; lamp current, $15 \mathrm{~mA}$; burner height, $0.9 \mathrm{~cm}$; slit width, $0.7 \mathrm{~mm}$; fuel flow rate, $31 \mathrm{~min}^{-1}$ and air flow rate $211 \mathrm{~min}^{-1}$.

\section{Preparation of the solid complexes}

From the aqueous solution. The solid complex was prepared by mixing equimolar amounts of HPTS and $\mathrm{Pt}(\mathrm{IV})$ in an aqueous ethanol solution. The mixture was heated under reflux in a water bath for $3 \mathrm{~h}$. The colored solid complex that precipitated was filtered off and recrystallized from ethanol, then dried in a vacuum desiccator.

From the scum. The complex isolated from the scum was obtained by mixing equimolar amounts of HPTS and $\mathrm{Pt}(\mathrm{IV})\left(1 \times 10^{-2} \mathrm{~mol}^{-1}\right)$ in presence of $3 \mathrm{ml}(6.36 \times$ $10^{-2} \mathrm{~mol} \mathrm{l}^{-1}$ ) oleic acid. The float (solid complex) was gathered by filtration in a sintered glass Gooch (G4), washed several times with doubly-distilled water, ethanol and finally with diethyl ether. The precipitate was dried in an oven at $80^{\circ} \mathrm{C}$ and stored in a desiccator.

\section{Procedures}

[a. Separation and determination of $\mathrm{Pt}(\mathrm{IV})$ in the aqueous solution]

Suitable concentrations of Pt(IV) and HPTS were mixed; then $3 \mathrm{ml}$ doubly-distilled water. The $\mathrm{pH}$ was adjusted to the optimum value. The solution was then transferred quantitatively to the flotation cell and completed to $10 \mathrm{ml}$ with doubly-distilled water. The cell was shaken well for few seconds to ensure complete complexation. To this solution, $3 \mathrm{ml}$ of HOL (having defined concentration) were added. The flotation cell was then inverted upside down twenty times by hand. After $10 \mathrm{~min}$, for complete flotation, the concentration of the metal ion in the mother liquor or in the scum was determined by atomic absorption. The floatability $(F \%)$ of the analyte was calculated from its concentration in the mother liquor according to the relation:

$$
F=\left[\left(C_{\mathrm{i}}-C_{\mathrm{f}}\right) / C_{\mathrm{i}}\right] \times 100 \%,
$$

where $C_{\mathrm{i}}$ and $C_{\mathrm{f}}$ denote the initial and final concentrations of the analyte, respectively.

Alternatively, the analyte concentration was directly measured spectrophotometrically or by atomic absorption, after elution with conc. $\mathrm{HNO}_{3}$ or by raising the temperature of the scum over $60^{\circ} \mathrm{C}$. The flotation efficiency was calculated from the relation

$$
F=\left(C_{\mathrm{s}} / C_{\mathrm{i}}\right) \times 100 \%
$$

where $C_{\mathrm{i}}$ and $C_{\mathrm{s}}$ are the initial and scum concentrations of the analyte, respectively.

[b. Separation and determination of $\mathrm{Pt}(\mathrm{IV})$ in real samples]

Each $0.01 \mathrm{~g}$ sample was taken and dissolved in $5 \mathrm{ml}$ aqua regia. The solution was slowly evaporated on a steam bath to almost dryness. It was cooled and dissolved with doubly-distilled water. The solution was filtered and completed to $50 \mathrm{ml}$ using doubly-distilled water. Into a flotation cell, $0.5 \mathrm{ml}$ of the above solution was introduced and the $\mathrm{pH}$ was adjusted to $c a .3$. To this, $1 \mathrm{ml}$ of HPTS $\left(0.05 \mathrm{~mol} \mathrm{l}^{-1}\right)$ was added and the volume was completed to $10 \mathrm{ml}$ with doubly-distilled water. The cell was shaken for $30 \mathrm{~s}$ to ensure complexation, then $3 \mathrm{ml}$ of oleic acid $\left(6.3 \times 10^{-3} \mathrm{~mol} \mathrm{l}^{-1}\right)$ were added and the cell was inverted upside down (by hand) twenty times for complete flotation. Two minutes after flotation were found to be enough to obtain a clear green scum layer. Such a layer was separated and an appropriate volume was introduced into the spectrophotometric cell for platinum determination at $690 \mathrm{~nm}$. The analyte content was calculated from the calibration curve which was constructed by taking different concentrations of chloroplatinic acid covering the basic range up to $10 \mathrm{ppm}$ platinum. The same aforementioned steps for flotation and determination were carried out. In all measurements, the concentration of HPTS as in the test solution was used as a blank.

\section{Results and Discussion}

\section{Separation and microdetermination of platinum(IV)}

Separation-flotation. Our experience ${ }^{9-12}$ in the flotation (solvent sublation) technique showed that oleic acid can be used safely as an excellent surfactant. For obtaining the maximum efficiency of separating microamounts of the analyte and for its determination, trials were made to choose the optimum conditions.

Initial experiments were carried out to float $5 \times 10^{-5}$ $\mathrm{mol}^{-1}(9.75 \mathrm{ppm})$ of platinum using different concentrations of oleic acid surfactant $(\mathrm{pH} \approx 3)$. The data in Fig. 1(a) show that the maximum separation does not exceed $25 \%$. In this case, platinum may float as oleate. It is worth noting that at such condition of flotation $(\mathrm{pH} \approx 3)$, oleic acid dissociates to a less extent, so insufficient oleate ions are present for complete separation. Therefore, oleic acid alone is not suitable for complete flotation at the $\mathrm{pH}$ required for alloy dissolution. The data clarify that the flotation of platinum, as its oleate, is not qualified from both economic and analytical points of view. Accordingly, its separation as another form is necessary. For this purpose, 4-phenylthiosemicarbazide is used. Figure 1(b) shows the role of HPTS in enhancing the flotation efficiency. For assured functioning, an excess amount of HPTS (tenfolds of Pt) is used. It can be seen from the figure that the flotation efficiency gradually increases as the HOL increases, attaining a maximum separation percent (ca. $100 \%)$ at $\geq 5 \times 10^{-4} \mathrm{~mol} \mathrm{l}^{-1}$ of HOL. Therefore, $1 \times 10^{-3} \mathrm{~mol}^{-1}$ of the surfactant was used throughout the subsequent studies.

To select a suitable concentration of HPTS required for complete separation of platinum, another series of experiments were carried out. The data in Fig. 2 show that the flotability increases, reaching $100 \%$ at $5 \times 10^{-4}$ 


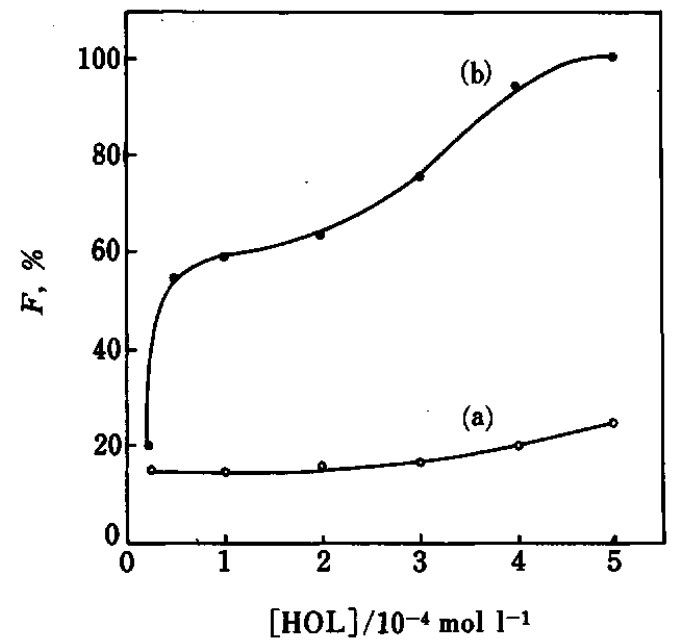

Fig. 1 Floatability of $5 \times 10^{-5} \mathrm{~mol} \mathrm{l}^{-1} \mathrm{Pt}$ (IV) using different concentrations of HOL at $\mathrm{pH} 3$. (a) without HPTS; (b) with $5 \times 10^{-4} \mathrm{moll}^{-1} \mathrm{HPTS}$.

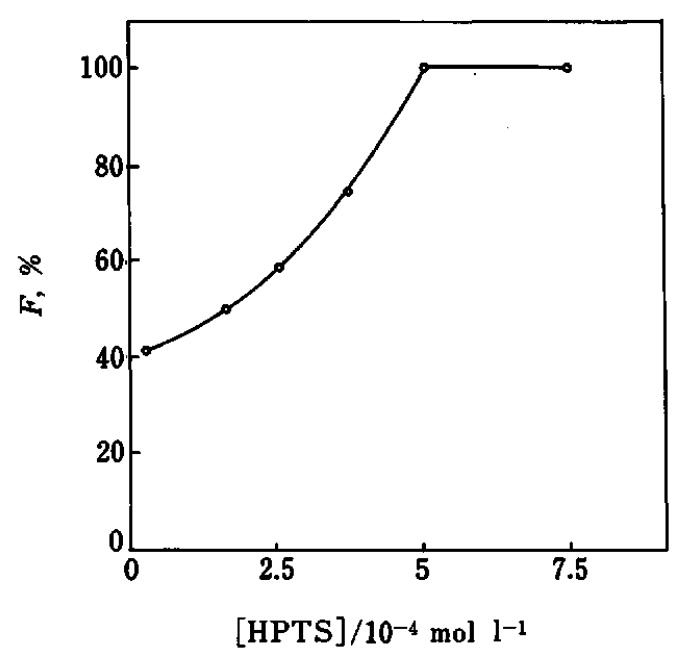

Fig. 2 Influence of HPTS concentration on the floatability of $5 \times 10^{-5} \mathrm{~mol} \mathrm{l}^{-1} \mathrm{Pt}$ (IV) using $1 \times 10^{-3} \mathrm{~mol}^{-1} \mathrm{HOL}$ at $\mathrm{pH} 3$.

mol ${ }^{-1}$. It is clear that tenfolds or more of HPTS are required for complete separation of $\mathrm{Pt}(\mathrm{IV})$. The need for this large amount may be due to: 1) platinum forms complexes with higher coordination number; it binds with a large number of HPTS or 2) a part of HPTS floats with HOL. The spectral data are in favor of the second assumption, in which two moles of HPTS react with one mol of Pt(IV). The rest $(8 \mathrm{~mol})$ may be floated with HOL. The selected concentration of HPTS for other experiments was $5 \times 10^{-4} \mathrm{~mol} \mathrm{l}^{-1}$.

To confirm the data in Fig. 2, another series of experiments were carried out to float different solutions containing variable amounts of platinum $\left(0.25-5 \times 10^{-4}\right.$ moll $\left.{ }^{-1}\right)$ in the presence and absence of $5 \times 10^{-4} \mathrm{~mol} \mathrm{l}^{-1}$ HPTS using $1 \times 10^{-3} \mathrm{~mol} \mathrm{l}^{-1} \mathrm{HOL}$ at $\mathrm{pH} \approx 3$. These are

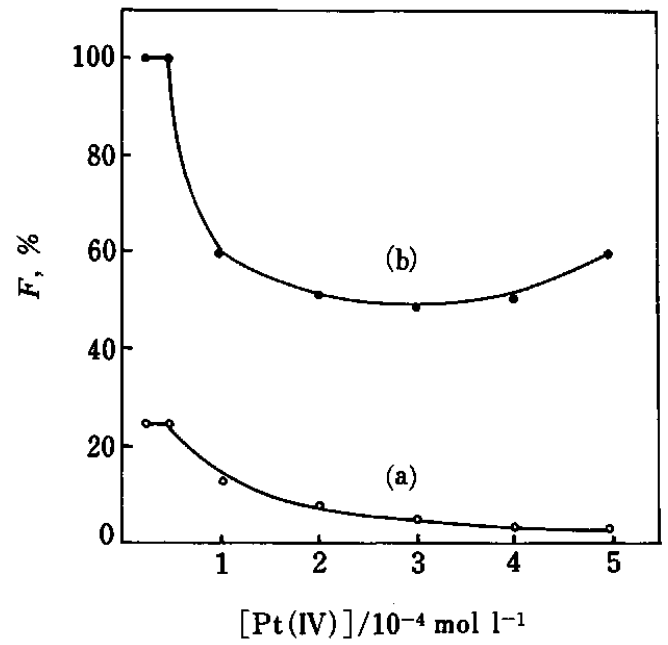

Fig. 3 Floatability of different concentrations of Pt(IV) using $1 \times 10^{-3} \mathrm{~mol}^{-1} \mathrm{HOL}$ at $\mathrm{pH} 3$. (a) without HPTS; (b) with $5 \times 10^{-4} \mathrm{~mol} \mathrm{l}^{-1}$ HPTS.

graphically represented in Fig. 3. In the absence of HPTS, Fig. 3(a), the maximum flotation (25\%) was achieved up to $0.5 \times 10^{-4} \mathrm{moll}^{-1}$ of platinum. On increasing the platinum concentration, the floatability decreases owing to the existence of insufficient amounts of oleate ions capable of floating all the platinum ions present. In the presence of $5 \times 10^{-4} \mathrm{moll}^{-1}$ HPTS, Fig. 3(b), the floatability reaches $100 \%$ at $1: 10$ ratio (Pt: HPTS) supporting the data in Fig. 2. Moreover, the addition of more than 10 times excess platinum has no pronounced effect on its separation. Consequently, in the separation of platinum from its natural unknown samples, excess HPTS can be safely added.

Different solutions containing the recommended concentrations $\left(5 \times 10^{-5} \mathrm{~mol}^{-1} \mathrm{Pt}, 5 \times 10^{-4} \mathrm{~mol} \mathrm{l}^{-1} \mathrm{HPTS}\right.$ and $1 \times 10^{-3} \mathrm{~mol} \mathrm{l}^{-1} \mathrm{HOL}$ ) were used to float $\mathrm{Pt}(\mathrm{IV})$ at different hydrogen ion concentrations. The data obtained are graphically illustrated in Fig. 4. As can be seen, in strong acidic solution $(\mathrm{pH}<3)$, the flotation efficiency decreases with decreasing the $\mathrm{pH}$ and completely vanishes at $\mathrm{pH} \leq 1.5$. At moderate hydrogen ion concentration $(3<\mathrm{pH}<7)$, the floatability reaches its maximum (ca. $100 \%$ ) value. In alkaline solution $(\mathrm{pH}>7)$, the flotation decreases owing to the formation of excessive foams of sodium oleates. ${ }^{13}$ Fortuitously, direct addition of the reagents attains the solution $\mathrm{pH}$ required for complete flotation $(\mathrm{pH} \approx 3)$.

Series of experiments containing platinum, HPTS and $\mathrm{HOL}$ at $\mathrm{pH} 3$ were conducted at different temperatures $\left(10-60^{\circ} \mathrm{C}\right)$. The data (Fig. 5) show that $100 \%$ flotation is achieved in the $10-30^{\circ} \mathrm{C}$ range. Raising the temperature above $30^{\circ} \mathrm{C}$, the flotation efficiency is gradually decreased, reaching a minimum value ( $c a$. zero) at $\geq 60^{\circ} \mathrm{C}$. The unstability of the species formed in the presence of HOL may be due to the decomposition of the bonds between oleic acid and Pt-HPTS species at these temperatures. 


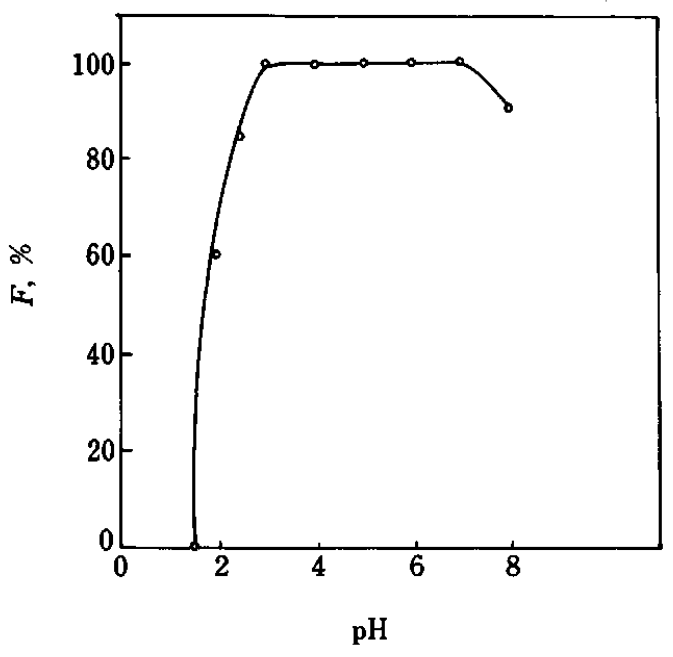

Fig. 4 Floatability of $5 \times 10^{-5} \mathrm{~mol}^{-1} \mathrm{Pt}(\mathrm{IV})$ using $1 \times 10^{-3}$ mol $1^{-1} \mathrm{HOL}$ in presence of $5 \times 10^{-4} \mathrm{~mol} \mathrm{l}^{-1} \mathrm{HPTS}$ at different $\mathrm{pH}$ values.

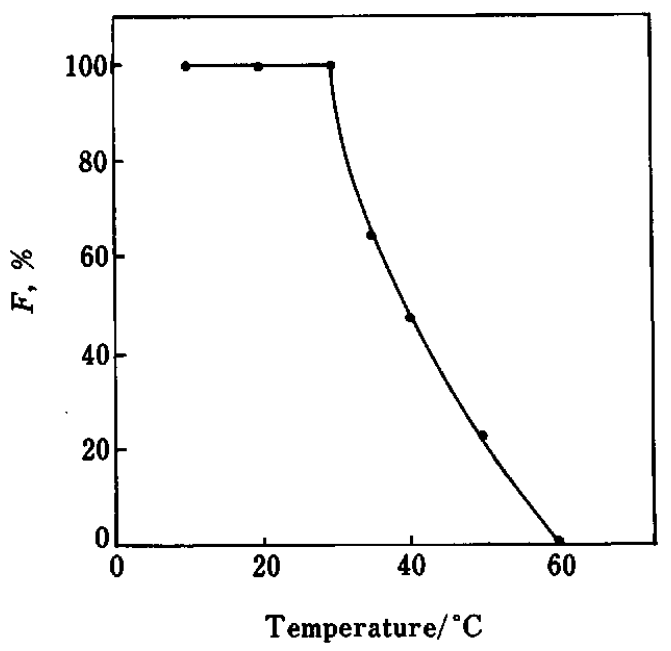

Fig. 5 Effect of temperature on the floatability of $5 \times 10^{-5}$ mol l-1 $\mathrm{Pt}(\mathrm{IV})$ in presence of $5 \times 10^{-4} \mathrm{moll}^{-1}$ HPTS and $1.0 \times 10^{-3} \mathrm{~mol} \mathrm{l}^{-1} \mathrm{HOL}$ at $\mathrm{pH} 3$.

\section{Spectrophotometric determination}

Figures 4 and 5 provide valuable data for complete elution of the total content of platinum either by heating $\left(\geq 60^{\circ} \mathrm{C}\right)$ or by acidifying the scum with $\mathrm{HCl}$ or $\mathrm{HNO}_{3}$ $(\mathrm{pH} \leq 1.5)$. The platinum content in the eluted solution was determined by atomic absorption as a confirmatory tool for supporting the proposed spectrophotometric procedure in this study which is based on the formation of a green colored complex between platinum and HPTS. This color becomes deep in the scum layer even at trace amounts of the original platinum.

The absorption spectra of Pt-HPTS system in the aqueous. solution and in the scum are completely different from that of platinum and HPTS. It is

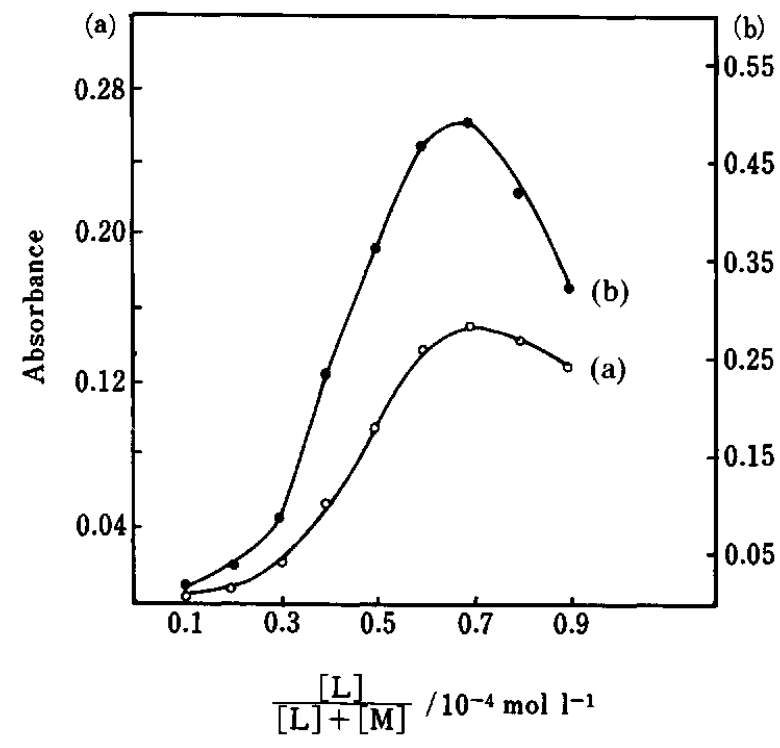

Fig. 6 Continuous variation method for (a) Pt-HPTS system at $660 \mathrm{~nm}$ and (b) Pt-HPTS-HOL system at $690 \mathrm{~nm}$.

observed that: 1) the $\lambda_{\max }$ of Pt-HPTS exhibits a red shift $(30 \mathrm{~nm})$ in the presence of $\mathrm{HOL}$ and 2) the absorbance of Pt-HPTS-HOL system is approximately twice that of PtHPTS. This proves that the species are concentrated in the presence of HOL. All the following spectrophotometric measurements were recorded at 660 and $690 \mathrm{~nm}$ for Pt-HPTS and Pt-HPTS-HOL systems, respectively. The stoichiometry of the complexes formed in solution and scum was ascertained by applying the continuous variation method. ${ }^{14}$ However, in all measurements, the same concentration of HPTS as in the test solution was used as a blank. The results (Fig. 6) reveal the possible formation of $1: 2$ (Pt: HPTS) species in the two systems. The apparent formation constants $\left(K_{\mathrm{f}}\right)$ of the complexes formed in the absence and presence of HOL are $1.31 \times 10^{9}$ and $2.98 \times 10^{9} \mathrm{l} \mathrm{mol}^{-1}$, respectively. Thus the stability of the species formed in the presence of $\mathrm{HOL}$ is higher than that obtained in its absence. Therefore, HOL stabilizes the formed complex more than water does. It has been found that Beer's law is obeyed up to $6 \times 10^{-5} \mathrm{moll}^{-1}$ $(11.7 \mathrm{ppm})$ and the molar absorptivity is $4.7 \times 10^{3} 1$ $\mathrm{mol}^{-1} \mathrm{~cm}^{-1}$ compared with $2 \times 10^{3} 1 \mathrm{~mol}^{-1} \mathrm{~cm}^{-1}$ calculated for the species in the aqueous solution. The regular enhancement in the absorbances and the higher molar absorptivity value in the presence of HOL could be attributed to the selective separation of Pt-HPTS using HOL surfactant. On the other hand, although the complex is formed in the aqueous solution and obeys Beer's law, its absorbance and $\varepsilon$ values are low. Such suppression may favor the determination after preconcentration. The limit of detection, which was calculated as the concentration that gives a reading equal to twice the standard deviation of a series of ten determinations taken with solutions of concentrations which are close to the level of the blank, was found to be $0.17 \mathrm{ppm}(8.8 \times$ 
Table 1 Effect of some foreign ions $\left(0.01 \mathrm{~mol}^{-1}\right)$ on the separation and determination of $2.4 \times 10^{-4} \mathrm{~mol}^{-1} \mathrm{Pt}(\mathrm{IV})$ in the presence of HPTS $\left(5 \times 10^{-4}\right.$ and $\left.5 \times 10^{-3} \mathrm{~mol} \mathrm{l}^{-1}\right)$

\begin{tabular}{|c|c|c|c|c|c|c|c|c|}
\hline \multirow{2}{*}{$\begin{array}{l}\text { Foreign } \\
\text { ion }\end{array}$} & \multicolumn{2}{|c|}{ Recovery, $\%$} & \multirow{2}{*}{$\begin{array}{c}\text { Foreign } \\
\text { ion }\end{array}$} & \multicolumn{2}{|c|}{ Recovery, \% } & \multirow{2}{*}{$\begin{array}{c}\text { Foreign } \\
\text { ion }\end{array}$} & \multicolumn{2}{|c|}{ Recovery, \% } \\
\hline & \multicolumn{2}{|c|}{$5 \times 10^{-4} \mathrm{~mol} \mathrm{l}^{-1} 5 \times 10^{-3} \mathrm{~mol} \mathrm{l}^{-1}$} & & \multicolumn{2}{|c|}{$5 \times 10^{-4} \mathrm{~mol} \mathrm{l}^{-1} 5 \times 10^{-3} \mathrm{~mol} \mathrm{l}^{-1}$} & & \multicolumn{2}{|c|}{$5 \times 10^{-4} \mathrm{~mol} \mathrm{l}^{-1} 5 \times 10^{-3} \mathrm{~mol} \mathrm{l}^{-1}$} \\
\hline $\mathrm{Cs}^{+}$ & 100 & 100 & $\mathrm{UO}_{2}{ }^{2+}$ & 100 & 100 & $\mathrm{Cu}^{2+}$ & 84 & 99.5 \\
\hline $\mathrm{Na}^{+}$ & 100 & 100 & $\mathrm{Hg}^{2+}$ & 100 & 100 & $\mathrm{Mn}^{2+}$ & 81 & 100 \\
\hline $\mathrm{K}^{+}$ & 100 & 100 & $\mathrm{~Pb}^{2+}$ & 100 & 100 & $\mathrm{Te}^{4+}$ & 78 & 100 \\
\hline $\mathrm{Ca}^{2+}$ & 100 & 100 & $\mathrm{Fe}^{3+}$ & 100 & 100 & $\mathrm{~W}^{6+}$ & 84 & 99.5 \\
\hline $\mathrm{Mg}^{2+}$ & 100 & 100 & $\mathrm{Sn}^{2+}$ & 100 & 100 & $\mathrm{Au}^{3+}$ & 81 & 100 \\
\hline $\mathrm{Sr}^{2+}$ & 100 & 100 & $\mathrm{Co}^{2+}$ & 72 & 100 & $\mathrm{Cd}^{2+}$ & 69 & 100 \\
\hline $\mathrm{Ag}^{+}$ & 100 & 100 & $\mathrm{Ni}^{2+}$ & 91 & 99.5 & & & \\
\hline
\end{tabular}

Table 2 Comparative results for the analysis of $\mathrm{Pt}(\mathrm{IV})$ in some alloys ${ }^{\mathrm{a}}$

\begin{tabular}{|c|c|c|c|c|}
\hline \multirow{2}{*}{ Alloy No. } & \multirow{2}{*}{ Composition, $\%$} & \multicolumn{3}{|c|}{$\mathrm{Pt}, \%$} \\
\hline & & Certificate & Present method & Relative error, $\%$ \\
\hline $63788 \mathrm{a}$ & $80 \mathrm{Cu}, 3 \mathrm{As}, 2 \mathrm{Mn}, 5 \mathrm{~V}$ & 10 & 10.06 & +0.60 \\
\hline $63786 \mathrm{e}$ & $80 \mathrm{Mn}, 5 \mathrm{Cr}$ & 15 & 15.09 & +0.60 \\
\hline $63786 f$ & $76 \mathrm{Co}, 9 \mathrm{Mo}, 3 \mathrm{As}, 2 \mathrm{~V}, 1 \mathrm{Si}$ & 9 & 8.97 & -0.33 \\
\hline $63786 \mathrm{~h}$ & $87 \mathrm{Zn}, 3 \mathrm{Mo}, 2 \mathrm{~V}, 2 \mathrm{Si}, 1 \mathrm{P}$ & 5 & 4.99 & -0.20 \\
\hline
\end{tabular}

a. Supplied by the "Department of Impression of Noble Metals and Weights".

$10^{-7} \mathrm{~mol} \mathrm{l}^{-1}$ ).

The possibility for the application of this procedure in the determination of trace amounts of platinum depends on the effect of foreign ions. The effects of numerous ions, which are naturally allied with platinum in its samples, were studied during the flotation and determination of platinum. The data are presented in Table 1. It is clear that $\mathrm{Cs}^{+}, \mathrm{Na}^{+}, \mathrm{K}^{+}, \mathrm{Ca}^{2+}, \mathrm{Mg}^{2+}, \mathrm{Sr}^{2+}$, $\mathrm{Fe}^{3+}, \mathrm{Ag}^{+}, \mathrm{UO}_{2}{ }^{2+}, \mathrm{Hg}^{2+}, \mathrm{Pb}^{2+}$ and $\mathrm{Sn}^{2+}$ have no effect. However, $\mathrm{Co}^{2+}, \mathrm{Ni}^{2+}, \mathrm{Cu}^{2+}, \mathrm{Mn}^{2+}, \mathrm{Te}^{4+}, \mathrm{W}^{6+}, \mathrm{Au}^{3+}$ and $\mathrm{Cd}^{2+}$ ions interfere to a large extent. All harmful and serious interferences were completely controlled by adding excess HPTS $\left(5 \times 10^{-3} \mathrm{~mol}^{-1}\right)$. Hence, one can predict that the interfering effects may be due to complex formation which is accompanied by lowering in the ligand concentration. Consequently, masking of the interfering effects by adding excess HPTS offers a highly selective procedure for the separation and determination of microamounts of platinum in its alloys.

\section{Application}

The aforementioned discussion introduces a good procedure for successful separation and determination of platinum in real samples. These were supplied from the "Department of Impression of Nobel Metals and Weights" and the results are listed in Table 2.

\section{Flotation mechanism}

In the studies concerning the separation via flotation followed by spectrophotometric determination, the role of surfactant is very important. The nature of interaction between oleic acid and Pt-HPTS must be studied to approach the actual mechanism of flotation. The proposed mechanism may proceed by forming a hydrogen bond between the hydrophilic part of HOL and the active sites in the ligand complex or by interaction between oleic acid and the complex, formed in solution, through a coordinate bond forming a self-floatable species (Pt-HPTS-HOL). In both cases, the hydrophobic part of the surfactant attached to the air bubbles and floats, separating the analyte containing species. The first proposal is more logical. Its sublate structure may be represented schematically as shown in Structure 1.

This suggestion is confirmed on the light of the following experimental data: 1) The platinum content of the solid complexes isolated in the absence and presence of oleic acid excludes HOL coordination. 2) The floated species have the same color (green) as that obtained in the aqueous solution (especially in high concentration of the reactants). 3) The i.r. spectra of the complexes isolated in the absence and in the presence of HOL are compared with that of the free ligand (Fig. 7a). In the complex spectrum isolated in the absence of $\mathrm{HOL}$ (Fig. 7b), a shift $\left(36 \mathrm{~cm}^{-1}\right)$ to lower wavenumber of $\delta\left(\mathrm{NH}_{2}\right)$ vibration indicates the participation of $\mathrm{NH}_{2}$ group in coordination. A higher shift by $15 \mathrm{~cm}^{-1}$ of the band at $1015 \mathrm{~cm}^{-1}$ due to $\nu(\mathrm{N}-\mathrm{N})$ in the spectrum of HPTS corroborates with the bonding through one of the hydrazinic nitrogens. The thioenolization process is supported by the disappearance of $\nu(\mathrm{C}=\mathrm{S})$ and $\nu(\mathrm{NH})$ bands observed at 785 and $3170 \mathrm{~cm}^{-1}$, respectively, in the i.r. spectrum of HPTS (Fig. 7a), with the appearance of new bands at 1580 and $720 \mathrm{~cm}^{-1}$ due to $\nu(\mathrm{C}=\mathrm{N})^{15,16}$ and $\nu(\mathrm{C}-\mathrm{S})^{17}$ vibrations, respectively. Coordination through the $\mathrm{C}-\mathrm{S}$ group is confirmed by the appearance of 


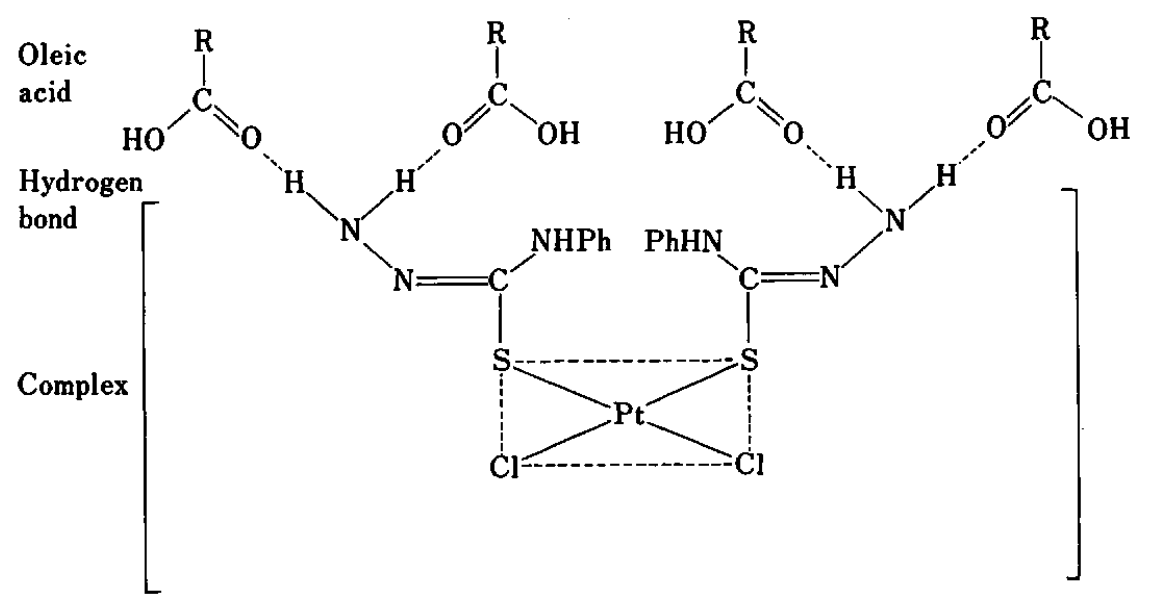

Structure 1 Schematic representation of the sublate.

$\nu(\mathrm{M}-\mathrm{S})^{17}$ at $500 \mathrm{~cm}^{-1}$. These observations confirm the monobasic bidentate nature of HPTS in the complex isolated in the aqueous solution. The i.r. spectrum of the complex isolated from the scum layer (Fig. 7c), in the presence of HOL, has a different behavior from that in its absence. The spectrum shows that the $\delta\left(\mathrm{NH}_{2}\right)$ vibration remains more or less at the same position as that in the free ligand, indicating that this group is not taking part in coordination. The same observations of thiol chelation are noticed. Moreover, the spectrum exhibits broad bands of medium intensity at 1950 and $2320 \mathrm{~cm}^{-1}$, which may be due to $\nu(\mathrm{N}-\mathrm{H} \cdots \mathrm{O})$ absorption ${ }^{18}$, suggesting that hydrogen bonding is a dominant factor in stabilizing the complex. The appearance of a band at $1700 \mathrm{~cm}^{-1}$ due to $\nu_{\text {as }}(\mathrm{COOH})$ of the carboxylic group is further evidence for the bonding of oleic acid through hydrogen bond. The coordination site of this complex is the thioenol group in which the ligand acts as a monobasic monodentate as shown in Structure 1. The band at $217 \mathrm{~cm}^{-1}$ in the spectrum of this complex, due to $\nu(\mathrm{M}-$ $\mathrm{Cl})^{19}$, is absent in the spectrum of HPTS. 4) The two complexes are diamagnetic in nature, confirming a square-planar structure ${ }^{20,21}$ around the platinum atom. This geometry is also confirmed by recording the electronic spectra of the two complexes in dimethylformamide solution. The spectra are similar and show one absorption band at $674 \mathrm{~nm}\left(14836 \mathrm{~cm}^{-1}\right)$. 5) The dissociation of $\mathrm{H}_{2} \mathrm{PtCl}_{6}$ as well as the formation of platinum complexes in the absence and presence of HOL were tested by the direct titration against $0.00147 \mathrm{~mol} \mathrm{l}^{-1}$ $\mathrm{KOH}$. The results (Table 3) indicate that $3.2 \mathrm{ml}$ of $\mathrm{KOH}$ is consumed liberating two protons from $\mathrm{H}_{2} \mathrm{PtCl}_{6}$ $\left(\mathrm{H}_{2} \mathrm{PtCl}_{6} \rightleftharpoons \mathrm{PtCl}_{4}+2 \mathrm{HCl}\right)$ whereas a negligible volume $(0.12 \mathrm{ml})$ is consumed for HPTS alone. In titrating $1: 1$ (Pt: HPTS) system, the volume is $4.1 \mathrm{ml}$, indicating that $1: 1$ species is formed simultaneously with evolution of one proton from the ligand $\left(\mathrm{PtCl}_{4}+\mathrm{HPTS} \rightleftharpoons \mathrm{PtCl}_{3}-\right.$ (PTS) $+\mathrm{HCl}$ ). Also, another proton is liberated in titrating a mixture containing $1: 2$ ratio and the volume of $\mathrm{KOH}(5 \mathrm{ml})$ supports $\mathrm{PtCl}_{3}(\mathrm{PTS})+\mathrm{HPTS} \rightleftharpoons$

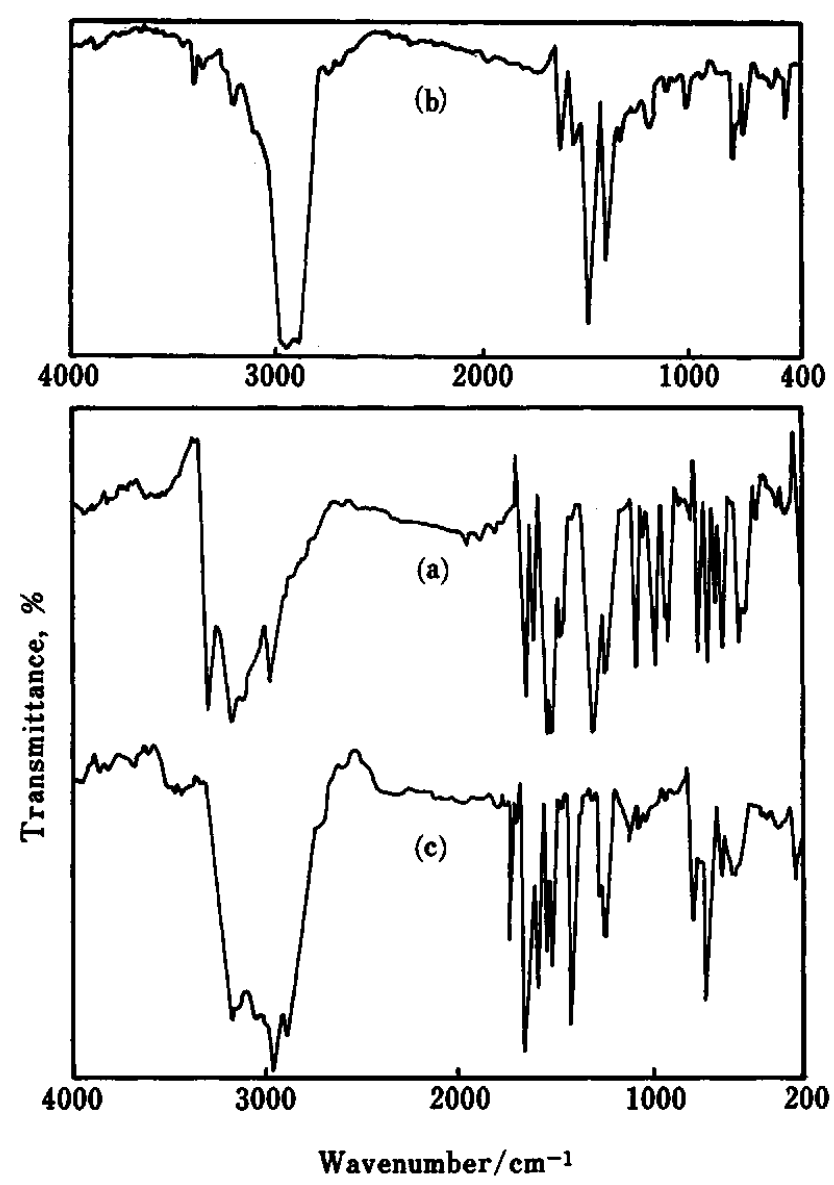

Fig. 7 Infrared spectra of (a) HPTS in $\mathrm{KBr}$, (b) Pt(IV)-HPTS isolated in aqueous solution in Nujol mull and (c) Pt(IV)HPTS-HOL isolated in oleic acid, in $\mathrm{KBr}$.

$\mathrm{PtCl}_{2}(\mathrm{PTS})_{2}+\mathrm{HCl}$. The role of $\mathrm{HOL}$ towards PtHPTS is clarified by its titration alone and in the presence of $1: 2$ species after flotation against $\mathrm{KOH}$. The free HOL needs $3.6 \mathrm{ml} \mathrm{KOH}$, whereas $8.9 \mathrm{ml}$ is needed for PtHPTS-HOL system; the latter experimental value 
Table 3 Titration of $\mathrm{H}_{2} \mathrm{PtCl}_{6}$, HPTS and HOL separately or in combination with $0.00147 \mathrm{~mol} \mathrm{l}^{-1} \mathrm{KOH}$

\begin{tabular}{lcccc}
\hline \multirow{2}{*}{ Solution } & \multicolumn{3}{c}{ Concentration $/ \mathrm{mol} \mathrm{l}^{-1}$} & Volume of KOH $/ \mathrm{ml}$ \\
\cline { 2 - 4 } & $\mathrm{H}_{2} \mathrm{PtCl}_{6}$ & HPTS & HOL & \\
\hline $\mathrm{H}_{2} \mathrm{PtCl}_{6}$ & $2 \times 10^{-3}$ & - & - & 3.2 \\
$\mathrm{HPTS}$ & - & $2 \times 10^{-3}$ & - & 0.12 \\
$\mathrm{H}_{2} \mathrm{PtCl}_{6}+\mathrm{HPTS}(1: 1)$ & $2 \times 10^{-3}$ & $2 \times 10^{-3}$ & - & 4.10 \\
$\mathrm{H}_{2} \mathrm{PtCl}_{6}+\mathrm{HPTS}(1: 2)$ & $2 \times 10^{-3}$ & $4 \times 10^{-3}$ & - & 5.00 \\
$\mathrm{H}_{2} \mathrm{PtCl}_{6}+\mathrm{HPTS}(1: 3)$ & $2 \times 10^{-3}$ & $6 \times 10^{-3}$ & - & 5.10 \\
$\mathrm{HOL}$ & - & - & $19.08 \times 10^{-4}$ & 3.60 \\
$\mathrm{H}_{2} \mathrm{PtCl}_{6}+\mathrm{HPTS}+\mathrm{HOL}$ & $2 \times 10^{-3}$ & $4 \times 10^{-3}$ & $19.08 \times 10^{-2}$ & 8.90 \\
\hline
\end{tabular}

exceeds the summation $(5.0+3.6)$ by $0.3 \mathrm{ml}$. This difference which in favor of Pt-HPTS-HOL is evidence for the easier replacement of carboxylic hydrogen when it interacts through a hydrogen bond.

In conclusion, all the mentioned studies confirm the first proposal mechanism.

\section{References}

1. S. Prakash, G. D. Tuli, S. K. Basu and R. D. Madan, "Advanced Inorganic Chemistry", S. Chand \& Company Ltd., New Delhi, 1983,

2. Z. Marczenko, Pure Appl. Chem., 57, 849 (1985).

3. X. He, Guijinshu, 12, 68 (1991).

4. Z. Li, J. Wang and Q. Xu, Mikrochim. Acta, 118, 43 (1995).

5. Q. Xu and Z. Xhou, Guijunshu, 10, 34 (1989).

6. Z. Morczenko and K. Kalinowski, Anal. Chim. Acta, 153, 219 (1983).

7. Z-L. Liu, W-B. Chang, J. Hong and Y-X. Ci, Analyst [London], 116, 213 (1991).

8. M. M. Mostafa, A. M. Shallaby and A. A. El-Asmy, J. Inorg. Nucl. Chem., 43, 2992 (1981).

9. M. A. Mostafa, S. E. Ghazy and M. A. Kabil, Analusis, 22, 440 (1994).

10. S. E. Ghazy, M. A. Kabil and M. A. Mostafa, J. Anal. At.
Spectrom., 9, 857 (1994).

11. M. A. Kabil and S. E. Ghazy, Sep. Sci. Technol., 29, 2535 (1994).

12. M. A. Kabil, S. E. Ghazy, M. A. Mostafa and A. A. ElAsmy, Fresenius' J. Anal. Chem., 349, 776 (1994).

13. Lemlich (ed.), "Adsorptive Bubble Separation Techniques", Academic Press, New York, 1972.

14. P. Job and C. R. Hebd, Sceances Acad. Sci., 1925, 180, 928; Ann., 9, 113 (1928).

15. A. A. El-Asmy, Synth. React. Inorg. Met-Org. Chem., 17, 399 (1987).

16. A. A. El-Asmy, Y. M. Shaibi, I. M. Shedaiwa and M. A. Khattab, Synth. React. Inorg. Met-Org. Chem., 210, 461 (1990).

17. L. J. Bellamy, "The Infrared Spectra of Complex Molecules", Methuen, London, 1958.

18. A. A. El-Asmy, T. Y. Al-Ansi, R. R. Amin and F. M. ElShahat, Trans. Met. Chem., 15, 12 (1990).

19. A. A. El-Asmy, M. M. Bekheit, K. M. Ibrahim and M. M. Mostafa, Synth. React. Inorg. Met-Org. Chem., 16, 1453 (1986). •

20. B. N. Figgis, "Introduction to Ligand Fields", Interscience, London, 1964.

21. A. B. P. Lever, "Inorganic Electronic Spectroscopy", Elsevier, Amsterdam, 1968.

(Received December 20, 1995) (Accepted February 13, 1996) 